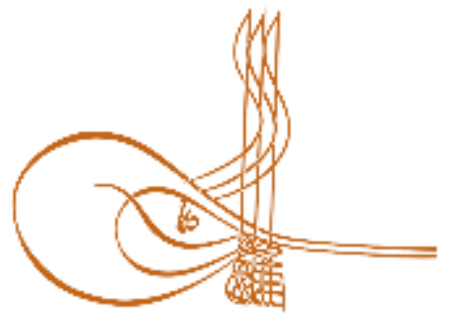

www.turkishstudies.net/turkishstudies
Turkish Studies

eISSN: $1308-2140$

Research Article / Araştırma Makalesi

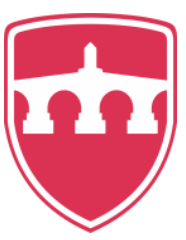

INTERNATIONAL

BALKAN

UNIVERSITY

Sponsored by IBU

\title{
Etkili Konuşma Özyeterlik Algı Ölçeğinin Geliştirilmesi: Geçerlilik ve Güvenirlik Çalışması
}

\begin{abstract}
The Development of Effective Speaking Self-Efficacy Perception Scale: Study on the Validity and
\end{abstract} Reliability

\author{
İbrahim Öztahtalı ${ }^{*}$ - Ersin Şahin ${ }^{* *}$
}

\begin{abstract}
The aim of this study was to develop a measurement tool for determining students' effective speaking self-efficacy perceptions. The study group of the research was composed of a total of 677 secondary school students (345 boys and 332 girls) receiving education at schools located in central districts of the province of Bursa during the 2016-2017 academic year, plus 10 domain experts. The students were selected by the random sampling method from 5 different secondary schools. At the scale development stage, 52 action items were created, and after the item-total correlation values of these items had been calculated, items with low values were removed from the scale, and exploratory and confirmatory factor analyses were performed by using the remaining 36 item data. After items had been removed according to the results of these analyses, the remaining 19 items were presented in a four-factor structure. The eigenvalues of the 4 factors, which explained $52.76 \%$ of the cumulative variance, were determined to be 3.918 for the first (phonetic) factor, 2.354 for the second (preparation) factor, 2.226 for the third(body language) factor and 1.282 for the fourth (mother tongue knowledge) factor, respectively. Regarding internal consistency of the scale as a whole, a Cronbach's alpha value of $\alpha=0.773$ was calculated. According to the results of the confirmatory factor analysis (RMSEA $=0.052$; SRMR=0.053; NNFI= 0.86; CFI =0.89), it was found that the model fit was at an acceptable level for the fit index values and also that the chi-square value $(342.696$; $\mathrm{p}<0.05)$ was significant, indicating that the data had the characteristic of normal distribution. Following the analysis performed for the scale validity, it was determined that there was a significant relationship between the application results $(\mathrm{r}=0.81 ; \mathrm{p}<0.01)$. The obtained findings are such as to support the idea that the present effective speaking scale has validity and reliability.
\end{abstract}

Structured Abstract: Aim and Importance of the Study The aim of the study was to present a practical scale with easy scoring and assessment which makes it possible to determine levels of effective speaking selfefficacy perception in students at secondary level.The scale which was developed and presented is considered

* Dr., Bursa Uludağ Üniversitesi, Güzel Sanatlar Bölümü

Phd Bursa Uludag Universty, Faculty of Fine Arts

ORCID 0000-0003-4964-8978

ibrahimoztahtal1@gmail.com

** Öğr. Gör. Dr., Bursa Uludağ Üniversitesi, Eğitim Fakültesi, Eğitim Bilimleri Bölümü

Lect., Dr. Bursa Uludag Universty, Faculty of Education, Education Science

ORCID 0000-0001-6800-7522

ersahin@uludag.edu.tr

Cite as/ Atıf: Öztahtalı, İ., Şahin, E. (2020). Etkili konuşma özyeterlik algı ölçeğinin geliştirilmesi: geçerlilik ve güvenirlik çalışmas1, Turkish Studies, 15(1), 565-582. https://dx.doi.org/10.29228/TurkishStudies.39967

Received/Geliş: 01 December/Aralık 2019

Accepted/Kabul: 25 February/Şubat 2020

Checked by plagiarism software

Copyright $(\mathbb{C}$ MDE, Turkey

Published/Yayın: 29 February/Şubat 2020

CC BY-NC 4.0 
important because of the contribution it can make to the field by the interpretation of data obtained in different research subjects and due also to its contribution to the development of different curricula and teaching activities for developing effective speaking skills in schools and other education institutions.

\section{Method}

This study is a scale-based study prepared with the aim of determining the construct validity and internal consistency reliability coefficient of the effective speaking scale. The study group was made up of students receiving education in secondary education institutions located in central districts of Bursa province during the 2016-2017 academic year. This consisted of a total of 677 secondary school students, made up of 219 high school students selected for the preliminary implementation, 368 students chosen for the actual implementation, and 90 students selected for the criterion validity and neutrality analyses. The students were selected by the random sampling method from 5 different secondary schools.

\section{Scale Development and Implementation Process}

During the development of the scale, an item pool was created by removing incoherencies and discrepancies following consultation with 10 domain experts, and a preliminary implementation was carried out by preparing a draft 5-point Likert-type scale consisting of 52 items. Next, according to the data obtained from the preliminary implementation, confirmatory factor analysis was performed, and after certain poorly operating items had been revised, the scale was reapplied to high school students. As a result of the operations, the items were revised and finalised, and a pool of 36 items was created. Following the other analyses, a fourfactor, valid and reliable scale consisting of 19 items was obtained and presented. The scale is an equallyspaced scale scored from 1 (never) to 5 (always). The lowest score that can be obtained from the scale is 19 , while the highest score is 95 .

\section{Data Analysis of the Scale}

The explanatory and confirmatory factor analysis and item analyses of the study were carried out with the SPSS 22.0 software package, and all the results obtained were tested bidirectionally.

\section{Findings}

\section{Findings Related to the Internal Consistency Reliability of the Measurement Tool}

According to the Cronbach's alpha value $(\alpha=0.73)$ and t-test results of the 36 -item test measurement tool, it was revealed that all the items included in the scale were significant $(p=0.000)$ and had distinctiveness in determining effective speaking self-efficacy perceptions.

\section{Findings Related to the Exploratory Factor Analysis}

Following the rotation of the exploratory factor analysis, a 4-factor structure with an eigenvalue greater than 1 and accounting for $52.76 \%$ of the total variance was determined.Items $5,6,7,10,11,12,13,16,17,19,20,21,23,24,25,26,27,28,32,34,35,37,38,40,41,42,44,45,46,49,50,51$ and 52 which had factor loadings below 0.45 , were removed from the scale.For the remaining 19 items, the 8 items in the first factor were named "Phonetic", the 4 items in the second factor were named "Preparation", the 4 items in the third factor were named "Body Language" and the 3 items in the fourth factor were named "Mother Tongue Knowledge". The internal consistency coefficients according to the Cronbach's alpha values calculated for the subdimensions of the scale and for the scale as a whole were determined to be 0.728 for the first factor, 0.762 for the second factor, 0.705 for the third factor, 0.699 for the fourth factor and 0.657 for the whole scale.

\section{Findings Related to the Confirmatory Factor Analysis}

In the confirmatory factor analysis, the RMSEA (Root Mean Square Error of Approximation), SRMR (Standardized Root Mean Square Residual), TLI(Tucker-Lewis Index),CFI(Comparative Fit Index) and chisquare model fit measures were taken into consideration for the structural fit.According to the results obtained, it was determined that the RMSEA value and SRMR value, which should be below 0.05 if a model is to fit, were 0.052 and 0.053 , respectively.Moreover, the NNFI value of 0.86 , CFI value of 0.89 and chi-square test statistic of $(2303,336)$ revealed that the data had normal distribution by taking $\mathrm{p}<0.05$ as significant. 


\section{Findings Related to the Measurement Validity}

To test the measurement validity of the scale, the "Teacher Candidates' Speech of Self Efficacy Scale" developed by Aydın (2013) was applied together with the developed scale to 90 students. As a result of the analysis made, a significant relationship was determined between the results of these two applications ( $\mathrm{r}=$ $0.82 ; \mathrm{p}<0.01)$.

\section{Findings Related to Neutrality}

In terms of neutrality in the subgroups in which the developed scale was applied, it was determined that the "preparation" dimension had a low reliability coefficient for 11th grade students and the "body language" dimension for students aged 14 and the "mother tongue" knowledge dimension for students aged 14 had low reliability coefficients. However, it was seen that the reliability coefficients for the other dimensions of the scale were above the required minimum level. In this case, no restriction was found for an assessment made based on the scores obtained in the other dimensions.

\section{Conclusion and Recommendations}

The internal consistency coefficient of the scale was found to be at a suitable level for both the scale as a whole and for the sub-factors. Moreover, since the scale also had to be reliable for the subgroups of the groups to which it was to be applied, evidence towards this was also examined. The gathered data revealed that the reliability level of the scale was weak "preparation" and "body language" and "mother tongue" sub-group. However, it was seen that the reliability levels of the other factors of the scale were adequate and that this subgroup had adequate reliability when the fourth factor was included in the scale as a whole. Moreover, it was understood that all other sub-groups of the scale had satisfactory levels of reliability. The developed scale was applied to students at the secondary level. However, it can be said that the scale may also be used at other educational levels. Furthermore, it can also be said that since the scale dimensions are not included in similar studies conducted, the necessary evidence of validity and reliability should be gathered to enable the scale to also be used with students at different levels.

Keywords: Effective Speaking, Act of Speaking, Scale Development.

Öz: Öğrencilerin etkili konuşma öz yeterlik algılarını belirlemeye yönelik ölçme aracı geliştirmek amacıyla yapılan bu araştırmanın çalışma grubunu, Bursa ili Merkez ilçelerinde bulunan ve 2016-2017 döneminde eğitim öğretime devam eden toplam 345 erkek $332 \mathrm{k1z}$ olmak üzere toplam 677 ortaöğretim öğrencisi ile 10 alan uzmanı oluşmuştur. Öğrenciler 5 farklı ortaöğretim okulundan tesadüfî yöntemle seçilmiştir. Ölçek geliştirme aşamasında 52 eylem maddesi oluşturulmuş, bu maddelerin madde-toplam korelasyon değerlerinin hesaplanmasından sonra değerleri düşük olan maddeler ölçekten çıkarılmış ve kalan 36 madde verileri kullanılarak Açımlayıcı ve Doğrulayıcı Faktör Analizleri yapılmıştır. Analiz sonuçlarına göre çıkarılan maddelerden sonra ölçekte kalan 19 madde dört faktörlü bir yapıda sunulmuştur. Yığılmalı varyansın \%52,76'sını açıklayan toplam 4 faktörün öz değerleri (eigenvalue) sırasıyla; birincinin (Sesletim) 3,918; ikincinin (Hazırlık) 2,354; üçüncünün (Beden Dili) 2,226 ve dördüncünün (Anadili Bilgisi) ise 1,282 tespit edilmiştir. Ölçeğin tümü için iç tutarlılık anlamında Cronbach $\alpha=0.773$ değeri olarak hesaplanmıştır. Doğrulayıcı analiz sonuçlarına göre (RMSEA $=0,052 ; \mathrm{SRMR}=0,053 ; \mathrm{NNFI}=0,86 ; \mathrm{CFI}=0,89$ uyum indeks değerlerine ait model uygunluğunun kabul edilebilir düzeyde ve Ki-kare (342.696; $<<0.05)$ değeri de anlamlı bulunarak verilerin normal dağılım özelliğine sahip olduğunu göstermiştir. Ölçüt geçerliği için yapılan analiz sonucunda uygulama sonuçları arasında anlamlı bir ilişki tespit edilmiştir $(r=0,81 ; p<0,01)$. Ulaşılan bulgular eldeki etkili konuşma ölçeğinin geçerlilik ve güvenirlik özelliğine sahip olduğunu destekler niteliktedir.

Anahtar Kelimeler: Etkili Konuşma, Konuşma Eylemi, Ölçek Geliştirme.

\section{Giriş}

Bilgiyi paylaşmanın en az kullanmak kadar önem taşıdığ günümüzde, etkili konuşma hem iletişimin hem de sosyal etkileşimin önemli bir bileşeni olarak bütün zamanlarda önem arz eden bir beceri olmuştur. Bilgiyi ifade etmenin önemli bir yolu olan konuşma insani vasıfların en önemlilerinden birisi olarak etkili ve doğru olduğu sürece, karşılıklı iletişim becerisini de istenen 
amaca ulaştırabilir. Konuşma, oluşturulacak iletinin içinde yer alması gereken gözlemlerin, düşüncelerin, duyguların ve ihtiyaçların zihinde kompoze edilmesi ve planlanmasıyla başlar. Planlı bir konuşma ise bir süreç olarak konuşma metninin oluşturulması ve uygulanmasıyla devam eder. İyi bir konuşma ancak iyi bir anadili bilgisiyle yapılabilir. Gözlem, düşünce, duygu ve ihtiyaçlarımızın ifadesinde en uygun kelimeleri bulabilmek, onların etki gücünü en yüksek olacak şekilde düzenleyerek uygun cümle yapılarında kurgulayabilmek gerekmektedir. Bunun için Türkçenin etkili bir biçimde konuşulmasının ilk ve en temel koşulu olan Türkçenin anlamsal işletim sisteminin de bilinmesi gerekir.

Alanyazında konuşmanın çeşitli tanımları yapılmıştır. Demirel'e (1999) göre konuşma, düşüncelerin, duyguların ve bilgilerin seslerden oluşan dil aracılığıyla aktarılmasıdır; Yörük'e (1998) göre, bir insanın başka bir insana ya da topluluğa duygu ve düşüncelerini sözle anlatmasıdır; Taşer'e (2000) göre zihinsel gelişimle birlikte kişilik oluşumunu da içeren ve temelde çok yönlü, çok karmaşık bir yapı olan konuşma; duygu, düşünce ve dileklerin görsel, işitsel öğeler aracılığı ile karşıdakilere iletmek, açıklamak, dışa vurmaktır; Ergenç'e (1999) göre, bir konunun zihinde tasarlandıktan sonra karşımızdakilere iletilmesi ve anlaşılmasıdır; Doğan'a (2005) göre, bireylerin kendi istek ve duygularını belli bir maksatla karşısındakilere iletebilmesidir; Yaman'a (2007) göre düşünme, muhakeme edebilme gibi özelliklerin sesler yardımıyla dışa vurulmasıdır. Öztahtalı'ya (2009) göre, gözlem, düşünce, duygu ve isteklerin anadili beceri ve kurallarıyla işlenip uygun zaman, mekan ve üslupla dile getirilmesi sürecidir; Yılmaz'a (2006) göre, diksiyon, dil, düşünce, beden dili ve üslup olmak üzere insanlar arasındaki en etkili iletişim aracıdır; Özdem'e (2003) göre aklımızı kullanma sanatı olmakla birlikte düşünceyi söze dönüştürmektir; Koç’a (2012) göre bir bütün olarak başkalarıyla iletişim kurmanın en etkin yolu ve doğru nefes almaktır; Karadağ'a (1997) göre fikir ve duyguların mimik ve jestlerle ifadeye konulmasıdır. Layiç'e (2007) göre ise konuşmanın en önemli destekleyicisi beden dilidir. Beden dili, bütün vücudunun bir orkestra gibi uyum içinde ve sözü destekleyen bir hareket zinciri içinde olmalıdır. Bu tanımlardan da anlaşılacağı üzere konuşmanın; beyinde oluşan bir iletinin ses organları vasıtasıyla iletişimi sağlamada ve bilgi aktarımında kullanılan bir beceri olduğu söylenilebilir. Konuşma hem fiziksel hem de zihinsel unsurlardan oluşmaktadır.

Etkili konuşma yeterliliği ise konuşma eyleminin bazı temel becerilerinin doğru şekilde yerine getirilmesiyle ilişkilidir. Öztahtalı, 2009'ya göre bu beceriler anadil bilgisi, konuşmaya hazırlık, nefesi doğru kullanma, artikülasyon (sesletim), durak, vurgu ve tonlama, sesi kullanma, beden dili gibi kullanım kabiliyetleriyle açıklanabilir. Konuşma becerisinin temelinde doğru ve tam soluma yani diyaframı kullanarak alınan tam kapasiteli nefes bulunmaktadır. Konuşmanın hammaddesi olarak düşünülmesi gereken hava yani nefes ne kadar çok ve ne kadar kontrollü olursa konuşmanın kalitesi de o kadar yükselmektedir. İnsanların doğuştan getirdikleri diyaframı etkin kullanarak yapılan soluma refleksi, zaman içinde zayıflayarak soluk alma kapasitesinin düşmesine neden olur ki bu da konuşmanın kalitesini olumsuz etkiler. İyi bir konuşmanın ilk adımı iyi bir nefestir. Tüm dillerin fonetik yapıları bazı benzerlikler olsa da birbirinden farklı gelişim tablolarına sahiptir. Anadili becerisi kazanılırken işitilen seslerin taklit edilmesi oldukça önemlidir. Dillerin kendi fonetik işletim sistemlerine göre kişi sesleri çıkarmayı öğrenir. Ses organları o dilin fonetik yapısına göre sese şekil vermeyi öğretir. Bu şekil; sesin dil, dudak ve çenenin kullanımıyla değiştirilmesinden oluşur ki alanyazında artikülasyon (sesletim) kavramıyla karşılanır. Konuşmacı, kendi dilinin en iyi konuşma ağzının fonetik yapısına uygun olarak sesleri, heceleri ve kelimeleri telaffuz etmeye çalışır. Telaffuz problemleri ise genellikle dil, dudak ve çene kullanımındaki tembellik ya da bozukluk nedeniyle ortaya çıkmaktadır(Öztahtalı,2009). Ayrıca Meiron ve Schick (2000)'e göre telaffuz ve sözcük seçimi de konuşmanın bütününü belirlemektedir.

Konuşmaya hazırlık, içeriğin niteliğinin arttırılmasının yanında uygulama sırasındaki profesyonel tutum için de gereklidir. Konuşmaya hazırlık, neyi, kim için, ne zaman, nerede, ne kadar, nasıl anlatılacağı sorularının cevaplandığı bir kısımdır. Konuşma sırasında konuşmanın zamanı ve 
konuşma yapılan mekanla birlikte, fiziksel koşullar oldukça önemlidir. Konuşmamız teknik açısından ne kadar mükemmel olursa olsun doğru zamanda ve doğru yerde yapılmıyorsa etkisi istenilen ölçüde gerçekleşmez. Burada esas olan dinleyicinin durumudur. Bir konuşmanın etkisi dinleyici ya da dinleyicilerinin hazır bulunuşluklarına ve konuşma sırasındaki tüm fiziksel koşullara bağlıdır. Dinleyicilerin nitelikleri ve konuşmanın durum bağlamı -yani konuşma sırasındaki tüm fiziksel koşullar- dikkate alınmadan yapılan bir konuşmanın başarılı olması beklenemez. Konuşmanın etkisi konusunda ne söylediğinizden daha çok, onu nasıl söylediğiniz önemlidir. Bunun içine durum bağlamla birlikte beden dili de girer. Beden dili, söylenilenlerin dinleyici tarafinda işitsel alg1 sisteminin yanında görsel algı sistemine de hitap etmesidir. İfade edilenin beden hareketleriyle desteklenmesi konuşmanın etkisini ettirdiği gibi dinleyicinin konuşmaya ve konuşmacıya odaklanmasını kolaylaştırır. Özellikle mimikler, sesimize yüklemek istediğgimiz duygu tonunun oluşmasını sağlayan önemli bir faktördür. Jest ve mimiklerle yani beden diliyle söylenenlerin senkronizasyonu konuşma etkisini arttırır. İnsan algısında sesin önemli bir rolü vardır. Ses, bir konuşmanın hem estetik hem de doğru yapılabilmesi için duyguyu açığa çıkaran enerjinin taşıyıcısıdır (Öztahtalı; 2009). Beyin ve hafızanın konuşmayla olan ilişkisi de konuşmanın zihinsel yönünü içermektedir (Temizyürek ve Ark., 2011). Seslerin çıkarılmasıyla birlikte kişinin kendi sesini tanıması, sesinin niteliklerini, bir bakıma sesinin rengini bilmesi onu daha etkin kullanabilmesini sağlar. Bunun için de dilin anlamsal işletim sisteminde yer alan durak, vurgu ve tonlama kurallarının doğru bilinmesi ve uygulanması gerekir

Eğitim öğretim süreçleri boyunca öğrencilerin karşılaştıkları konuşma sorunlarını fark ederek etkili konuşma beceri düzeyleri hakkında bilgi sahibi olmaları ve konuşma yeterlikleri hakkında farkındalık geliştirmeleri akademik başarıları için gereklidir. Ülkemizde çeşitli öğretim kademelerinde yer alan öğrencilerin konuşma becerilerinin ölçülmesinin amaçlandığ 1 araştırmalar için çeşitli formlar kullanılmıştır. Örneğin Öztürk (2002), üniversite öğrencilerinin sözel anlatım becerilerini tespit etmek amacıyla gözleme dayalı yaptığı araştırmasında, "söyleyiş", "anlamlandırma", "plân" ve "sözel olmayan anlatım becerileri" içeren formla öğrencilerin konuşmalarını değerlendirirken, Sargın (2006), "konuşma düzeni, dil bilinci (bilgi ve dili kullanma becerisi) ve konuşmacının psikolojik durumu" olmak üzere üç ana başlıktan oluşan "Konuşma Değerlendirme Formu"nu kullanmıştır. Yine Sallabaş (2011), "konuşmaya başlangıç, konuşmanın gelişme ve sonuç bölümü, beden dili, dilin yapı unsurlarını uygulayabilme" bölümlerinden oluşan dereceli puanlama anahtarını kullanmıştır. Bozkurt (2017) tarafından geliştirilen konuşma becerisine yönelik beş boyuttan oluşan (söyleyiş, akıcılık, dil yetkinliği, içerik, etkileşim) konuşma becerisi değerlendirme çerçevesi oluşturulmuştur. Konuşma becerisini ölçme ve değerlendirmede kullanılan bu ölçekler ve formlar incelendiğinde, ele alınan boyutların; dikkat, etkili sunum (ACTFL, 1999; Douglas, 1994, MEB, 2006); ses kullanımı (Meiron \& Schick, 2000; Sargın, 2006), etkili ve doğru anlatım (Douglas, 1994; ETS, 2001, Öztürk, 2002, MEB, 2006) ve dinleyicileri dikkate alma başlıklarında toplandığı görülmektedir (Council of Europe, 2001; Sallabaş, 2011).

Ülkemizde geliştirilen ve sonradan uyarlanan konuşma ölçekleri ve bu ölçeklere ait alt boyutlar incelendiğinde ise, özellikle hazırlık ve sesletim boyutlarına yer verildiği ancak anadili bilgisi ve beden dilini etkili kullanabilme becerilerini ölçebilecek alt boyutlara yer verilmediği belirlenmiştir. Örneğin; Sevim (2012) tarafindan geliştirilen Konuşma Kaygısı Ölçeği, konuşmacı odaklı kaygı ve çevre odaklı kaygı ve konuşma psikolojisi olarak üç boyutludur. Erdem ve Erdem (2014) tarafından geliştirilen Dinleme Ve Konuşma Yeterliği Ölçeği, dinleme, konuşma, dinlediğini anlama ve sözlü anlatım olmak üzere dört boyutludur. Aydın (2013) tarafından geliştirilen Konuşma Özyeterlik Ölçeği; konuşmayı planlama, konuşma süreci, dilsel yapı ve dinleyici faktörü olmak üzere dört boyutludur. Sofu (2012) tarafindan geliştirilen Konuşma Kaygısı Ölçeği tek boyutludur. Sallabaş (2013) tarafından geliştirilen Konuşma Özyeterlik Algı Ölçeği, genel konuşma yeterlikleri ve konuşmanın şekil özellikleri olmak üzere iki boyutludur, Akın ve Ark. (2017) tarafından uyarlanan Konuşmacıda Kişisel Güven Ölçeği ise tek boyutludur. Bu ve benzeri ölçeklerdeki 
konuşma becerisini hedef alan ölçme araçları, adlandırma, ölçek türleri ve becerinin alt boyutları (Bozkurt 2017) bakımından farklılıklar göstermektedir. Bu nedenle de bu araştırmada orta öğretim seviyesindeki öğrencilerin etkili konuşma özyeterlik alg1 düzeylerini ölçebilmek açısından puanlanması ve değerlendirilmesi kolay, kullanışlı, geçerli ve güvenilir bir "Etkili Konuşma Özyeterlik Algı Ölçeği” geliştirmek amaçlanmıştır. Ayrıca ölçeğin geliştirilmesi sırasında hedef kitlenin özelliklerine uygun bir çalışma grubundan veri toplanması da ölçeğin psikometrik özellikleri yansıtma gücü bakımından önemli görülmüştür. Geliştirilen ve sunulan ölçek sayesinde elde edilecek farklı araştırma konularına ait verilerin çözümlenmesinin dil eğitimi alanına katkı getirilebileceği ve etkili konuşma becerilerinin geliştirilmesi için okullarda ve diğer eğitim kurumlarında farklı ders programlarının ve öğretim etkinliklerinin geliştirilmesine de destek olması açısından da önemli bulunmuştur.

\section{Yöntem}

$\mathrm{Bu}$ bölümde araştırmada kullanılan model, araştırmanın katılımcıları ve araştırma veri toplama araçları ile verilerin analizi açıklanmıştır. Bu araştırma, etkili konuşma özyeterlik alg1 ölçeğinin yapı geçerliliğini ve iç tutarlılık güvenirlik katsayısını belirlemeye yönelik olarak hazırlanan ölçekleme temelli bir çalışmadır. Ayrıca bir grubun belli başlı birtakım özelliklerini belirlemek için gruptaki bireylerin görüşlerinin ve tutumlarının belirlenmesine çalışılan tarama modeli kullanılmıştır.

\section{Evren ve Örneklem}

Araştırmanın evrenini 2016-2017 döneminde Bursa ili genelindeki okullar ve örneklemini ise Osmangazi, Yıldırım ve Nilüfer merkez ilçelerindeki düşük, orta ve yüksek sosyo-kültürel çevreden seçilen üç ortaöğretim kurumuna devam eden öğrenciler oluşturmuştur. Araştırmanın örneklemini; madde havuzunu oluşturmak için görüşülen 10 alan uzmanı, görüşmeden elde edilen veriler doğrultusunda düzenlenen maddelerin ön uygulaması için seçilen 219 lise öğrencisi, açımlayıcı faktör analizi için seçilen 184 ve doğrulayıcı analiz için seçilen 184 olmak üzere birlikte 368 öğrenci ve ölçüt geçerliği ile yansızlık analizleri için seçilen 90 öğrenci olmak üzere toplam 677 ortaöğretim öğrencisi oluşturmuştur.

\section{Kullanılan Veri Toplama Araçları}

Ölçeğin ölçüt geçerliğini sınamak için veri toplamak amacıyla Aydın (2013) tarafından geliştirilen öğretmen adaylarının konuşma öz yeterliklerine ilişkin ölçek kullanılmıştır. Ölçek "Konuşmayı Planlama”, "Konuşma Süreci”, "Dilsel Yapı" ve "Dinleyici Faktörü” olmak üzere dört boyutludur. Güvenirlik analiz değerleri incelendiğinde 1. Faktörün 94, 2. faktörün. 87, 3. faktörün .89 , 4. faktörün .74 ve ölçeğin bütünü için de .95 alfa katsayısına sahip olduğu görülmektedir. Geliştirilen bu ölçeğin konuşma becerisini öz yeterlik algısı bakımından değerlendirmede sağlıklı bir araç olduğu ifade edilebilir. Aydın (2013) tarafından geliştirilen ölçek de "Sesletim" "Hazırlık", "Beden Dili" ve "Anadili Bilgisi" olmak üzere benzer biçimde dört faktörlü bir yapıya sahiptir. Ayrıca ölçeklerin ikisinin de iç tutarlılık katsayı değerlerinin kabul edilebilirlik düzeyinde bulunması ve boyutlandırılmaları (Konuşmayı planlama/ Hazırlık; Konuşma süreci/Sesletim; Dilsel yapı/Anadili Bilgisi) bakımından uyumlu olmaları nedeniyle ölçüt geçerliğinin tespit edilmesi için kullanılmasının uygun olduğuna karar verilmiştir. Ancak ölçeklerin boyutlandırılması benzerlik taşımakla birlikte bire bir aynı olmadığı da ortaya konmuştur. Araştırmada kullanılan ölçeğin geliştirilmesi, uygulanması süreçleri ile puanlanması aşağıda açıklanmıştır.

\section{Ölçeğin Geliştirilmesi Süreci}

Ölçeğin geliştirilmesi amaciyla, Türkiye'de ve diğer ülkelerde geliştirilen ve Türkçeye uyarlanan "konuşma becerisi" ve "konuşma yeterliği" başlıklı ölçekler dikkate alınmıştır. Ayrıca ölçeğin geliştirilmesine ve alandaki boşluğu doldurmasına temel dayanak olabilecek son yıllarda yapılan alanyazındaki bazı çalışmalar da incelenmiştir. Örneğin; Ulum ve Taşkaya (2017) 
tarafından yapılan ve günümüz öğrencilerinde bir sorun olarak tespit edilen konuşma bozukluklarına ait araştırma sonuçları, Kuru (2013) tarafindan önemli bir problem olarak tespit edilen ve öğrencilerin akıcı konuşma sorunlarını gidermeye yönelik çözümler önerileri, Erdem(2013) tarafından özellikle konuşma eğitimleri sırasında karşılaşılan sorunlar ve güçlükleri ortaya koyan görüşleri dikkate alınarak alana katkı sağlayabilecek ve farklı boyutlardan meydana gelen etkili konuşma ölçeğinin maddelerinin oluşturulma hazırlığı yapılmıştır. Ardından 10 alan uzmanı ile görüşülerek anlamsal bozukluklar ve tutarsızlıklar giderilerek madde havuzu oluşturulmuş ve 52 maddeden oluşan 5'li Likert tipi taslak ölçek hazırlanmıştır. Taslak ölçek ön uygulama da kullanılarak nicel veriler toplanmıştır. Madde-toplam korelasyon değerlerinin hesaplanmasından sonra değerleri düşük olan maddeler ölçekten çıkarılmış ve maddelere son şekli verilerek 36 maddelik havuz yapılmıştır. Maddelerin 28'inin olumlu, 8'i ise olumsuz yapıdadır. Elde edilen verilerden hareketle, 36 madde için ayırt edicilik analizi, açıklayıcı ve doğrulayıcı faktör analizleri yapılmış, ölçeğin güvenirlik katsayıları hesaplanmışır.

\section{Ölçeğinin Uygulanması Süreci}

Ölçeğin ön uygulaması için farklı üç lisenin 10, 11 ve 12. sınıflarında yer alan 120 kız ve 99 erkek olmak üzere 219 öğrenciden veri toplanmıştır. Ölçeğin güvenirlik katsayısının da hesaplandığı asıl uygulama verileri ise, açımlayıcı faktör analizi için 184 ve doğrulayıcı faktör analizi için 184 öğrenci olmak üzere üç farklı liseden toplanmış ve toplam 368 lise öğrencisine ulaşılmıştır. Veriler üzerinde öğrencilerin eksik işaretleme yapmaları yüzünden 19 öğrenciden alınan veri değerlendirmeye dahil edilmemiştir. Geriye kalan 349 öğrenciden alınan veri değerlendirmede kullanılmıştır. Öğrencilerin 116'sı 10. sınıf, 116's1 11. sınıf, 117'si 12. Sınıfta öğrenim görmektedir. Son olarak; Aydın (2013) tarafından geliştirilen "Öğretmen Adaylarının Konuşma Öz Yeterliklerine İlişkin Ölçek" üç farklı sosyo-ekonomik düzeye sahip okullardaki 10, 11 ve 12 . sınıflardaki lise öğrencilerine uygulanmış ve geliştirilen ölçeğin ölçüt geçerliliği ile ilgili kanıt toplamak ve alt gruplardaki güvenirlik katsayılarını hesaplamak için toplam 90 öğrenciden veri toplanmıştır.

\section{Etkili Konuşma Özyeterlik Algı Ölçeğinin Puanlanması}

Etkili Konuşma Özyeterlik Algı Ölçeği, 1 (hiçbir zaman) ile 5 (her zaman) arasında puanlanan eşit aralıklı bir ölçektir. Öğrencilerin maddelerde yer alan davranışlara ait tepkilerini kendilerine en uygun; Hiçbir zaman (1), Nadiren (2), Bazen (3), Sıklıkla (4) ve Her zaman (5) biçiminde işaretlemeleri beklenmiştir.

\section{Veri Analizi}

Araştırmanın açımlayıcı ve doğrulayıcı faktör analizi çalışmaları ile madde analizi çalışmaları SPSS 22.0 paket programıyla gerçekleştirilmiş ve elde edilen tüm sonuçlar çift yönlü olarak sınanmıştır.

\section{Bulgular}

Bu bölümde araştırmada kullanılan açımlayıcı ve doğrulayıcı faktör analizine ilişkin bulgular ile ölçme aracına ait iç tutarlılık güvenirlik değerleri ve aracın ölçüt geçerliği ile yansızlığına ait bulgulara yer verilmiştir.

\section{Ölçme Aracının Geçerlik Çalışması}

Yap1 geçerliliği ölçme aracında yer alan maddelerin ölçülmek istenen özellikle yüksek düzeyde ilişki vermesi ve faktörler arasındaki ilişkilerin de kurama uygun olması durumunu ifade etmesi olarak kabul edilebilir (Yaşar,2014). Ölçeğin yapı geçerliliği çalışmasında önce açımlayıcı faktör analizine yer verilmiş ardından ölçek modelinin toplanan araştırma verisi tarafından doğrulanma düzeyini incelemeye yarayan (Noar 2003; Karatay,2009) doğrulayıcı faktör analizi yapılmıştır. 


\section{Açımlayıcı Faktör Analizine Yönelik Bulgular}

Açımlayıcı Faktör analizi gözlenemeyen ve ölçülemeyen gizli boyutları ortaya çıkarmayı sağlar. Bartlett testi ile korelasyon matrisinin istatistiki olarak anlamlılığına bakılabilir ve KMO testi yapılarak da değişkenler arasındaki korelasyonlar ölçülebilir. KMO testinin değeri 0 ile 1 aralığında ve 1'e yakın olmalıdır. Johnson ve Winchern, 2014; Kalaycı, 2006; Yaşlığlu, 2017). Veri grubunun faktör analizine uygun olup olmadığının belirlemek amacıyla yapılan Kaiser-MeyerOlkin (KMO) testi ve küresel olup olmadıklarını belirlemek için yapılan Bartlett testi sonuçları Tablo 1'de verilmiştir;

Tablo 1: Etkili Konuşma Özyeterlik Alg1 Ölçei’neAit KMO ve Bartlett's Test İstatistikleri

\begin{tabular}{lr}
\hline Kaiser-Meyer-Olkin (KMO) Örneklem Uygunluğu Ölçüsü &, 792 \\
Bartlett's Küresellik Testi Yaklaşık Ki-Kare Değeri & 2303,336 \\
Serbestlik Derecesi (sd) & 171 \\
Anlamlılık Düzeyi (Sig.) & 0.00 \\
\hline
\end{tabular}

Tablo 1'e göre, KMO testi ölçüm değerinin 0,792, Bartlett Sphericity testi ki kare değerinin ise 2303,336 ( $\mathrm{sd}=171, \mathrm{p}=.000)$ olduğu tespit edilmiştir. KMO değerinin 0,70 üzerinde olmas1 veri setinin faktör analizi yapmak için uygun düzeyde olduğu şeklinde yorumlanmaktadır (Field, 2000). 0,71- 0,80 değerinin orta, 0,81-0,90 değerinin iyi,0,90 üzerinde olan değerin ise mükemmel olduğunu belirtilmiştir (Şencan, 2005; Çokluk, Şekercioğlu ve Büyüköztürk, 2012; Yaşar, 2014). Bartlett testi sonucunda da sıfir hipotezi .05 anlamlılık düzeyinde reddedilmiş ve araştırma için toplanan verilerin açımlayıcı faktör analizi yapmak için yeterli olduğuna karar verilmiştir.

Döndürülmüş faktör analizinde Varimax yöntemi kullanılmıştır. Sonuçlar değerlendirilirken öz değeri (eigenvalue) 1 'in üzerinde olan faktörler anlamlı kabul edilerek dikkate alınmıştır. Faktör yüklerinin incelenmesinde minimum değer olarak.33 kabul edilmiştir. Ayrıca yapıyı belirlemede yığılma grafiğinin kırılma noktası da dikkate alınmıştır. Ölçeğin son halinin yı ̆̆ılma grafiği aşağıdaki gibidir;

\section{Şekil 1: Etkili Konuşma Özyeterlik Alg1 Ölçeğinin Yığılma Grafiği}

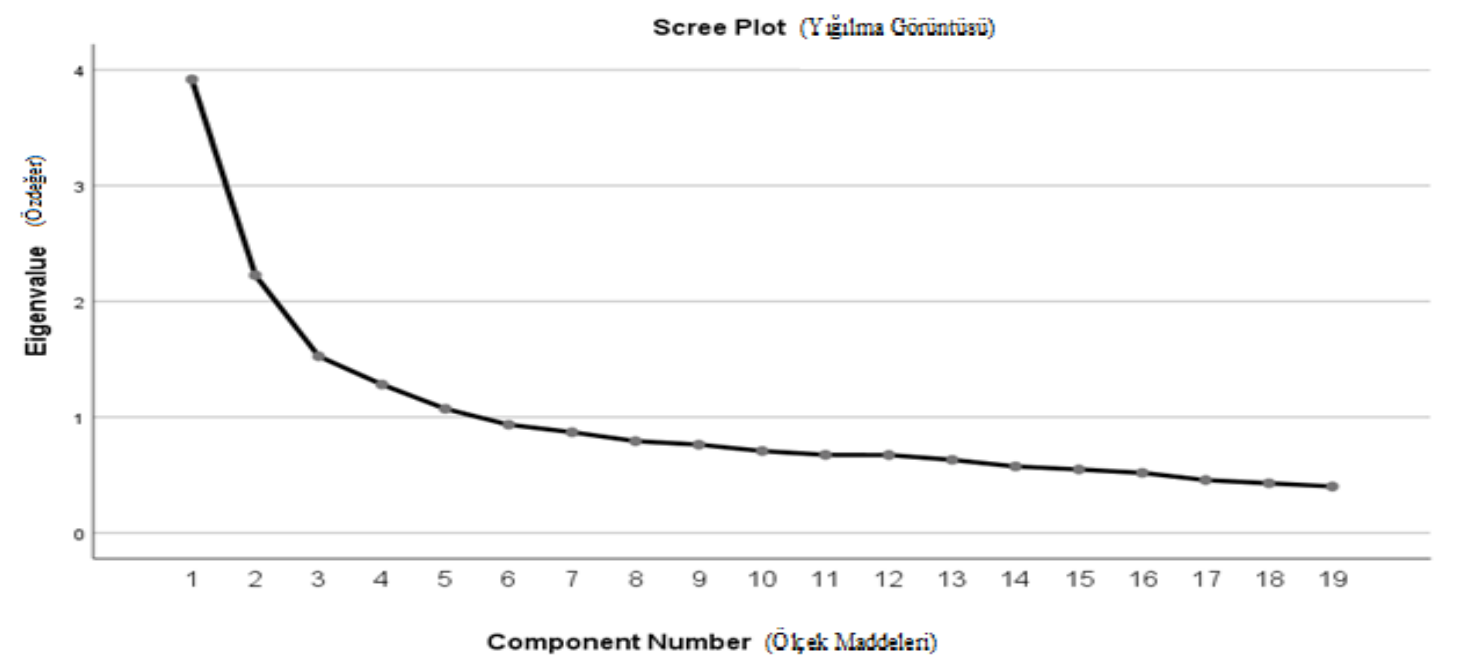

Şekil 1'deki yığılma grafiğgine bakıldığında dördüncü bileşenden sonra keskin iniş görülmediğinden bu ölçekteki faktör belirlemedeki kesme noktasının dört olması anlamlı 
görülmüştür. Sonçta, öz değeri (eigenvalue) 1 'in üzerinde olan ve toplam varyansın \% 56,83'ünü açıklayan 4 faktörlü bir yapı tespit edilmiştir. Faktör yükü.33'ün altında olan $5,6,7,10,11,12,13,16,17,19,20,21,23,24,25,26,27,28,32,34,35,37,38,40,41,42,44,45,46,49,50,51$ ve 52. maddeler ölçekten çıkarılmıştır. Ayrıca dört dışındaki faktörlerde bulunan maddelerin kuramsal olarak anlamlı kümelenmediği görülerek bu maddelerin de ölçekten çıkarılmasına karar verilmiştir. Döndürme sonrasında geriye kalan dört faktörde yer alan 19 madde ölçeğe alınmıştır. Birinci faktörde 8 maddenin, ikinci faktörde 4 maddenin, üçüncü faktörde 4 maddenin ve dördüncü faktörde de 3 maddenin toplandığ tespit edilmiştir. Faktörlerin örüntüsel matriksleri Tablo 2'de verilmiştir;

Tablo 2: Etkili Konuşma Özyeterlik Algı Ölçeğinin Faktörleri ile Faktörlere Ait Yük Değerleri

\begin{tabular}{|c|c|c|c|c|c|}
\hline \multirow{2}{*}{\multicolumn{6}{|c|}{$\begin{array}{c}\text { Dağılımı } \\
\text { Faktörler }\end{array}$}} \\
\hline \multicolumn{5}{|c|}{ Faktörler } & \\
\hline $\begin{array}{l}\text { Mad. } \\
\text { No }\end{array}$ & $\begin{array}{l}\text { Ölçeğin Tek Faktörüne Ait } \\
\text { Yük Değerleri (Eksen } \\
\text { Döndürme Yapmadan) }\end{array}$ & Sesletim & Hazırlık & $\begin{array}{c}\text { Beden } \\
\text { Dili }\end{array}$ & $\begin{array}{l}\text { Anadili } \\
\text { Bilgisi }\end{array}$ \\
\hline M36 & ,449 & ,871 & & & \\
\hline M3 & ,588 & ,806 & & & \\
\hline M47 & ,560 & ,775 & & & \\
\hline M39 & ,546 & ,729 & & & \\
\hline M4 & ,567 & ,711 & & & \\
\hline M31 & ,516 & ,697 & & & \\
\hline M48 & ,533 &, 673 & & & \\
\hline M29 & ,472 & ,644 & & & \\
\hline M14 & ,416 & & ,776 & & \\
\hline M9 & ,595 & & ,771 & & \\
\hline M43 & ,471 & & 737, & & \\
\hline M15 &, 570 & & ,641 & & \\
\hline M33 & ,579 & & & ,799 & \\
\hline M18 & ,528 & & & ,702 & \\
\hline M2 & ,496 & & & ,688 & \\
\hline M8 & ,539 & & &, 577 & \\
\hline M22 & ,669 & & & &, 814 \\
\hline M30 & ,520 & & & & ,695 \\
\hline M1 & ,410 & & & &, 523 \\
\hline \multicolumn{2}{|c|}{ Cronbach Alfa $(\alpha), 728$} & ,762 & ,705 & ,699 & ,657 \\
\hline \multicolumn{2}{|c|}{ Faktörlere Ait Özdeğerler } & 3,918 & 2,354 & 2,226 & 1,282 \\
\hline \multicolumn{2}{|c|}{$\begin{array}{l}\text { Açıklanan Yı̆̆ılmalı } \\
\text { Varyans Yüzdesi }\end{array}$} & 37,334 & 42,370 & 47,119 & 52,760 \\
\hline
\end{tabular}

Tablo 2‘ye göre maddelerin faktör yüklerin ,523 ile ,871 arasında değiştiği görülmektedir. Ayrıca döndürme sonrasında öz değeri (eigenvalue) birin üzerinde olan ve yığılmalı varyansın \% 52,76'sını açıklayan toplam 4 faktörün öz değerleri (eigenvalue) sırasıyla; birincinin 3,918; ikincinin 2,354; üçüncünün 2,226 ve dördüncünün ise 1,282 tespit edilmiştir. Ölçeğin dört faktörlü yapısına göre; birinci faktörde yer alan ilk 8 madde "Sesletim" ikinci faktördeki 4 madde "Hazırlık", üçüncü faktördeki 4 madde "Beden Dili" ve dördüncü faktördeki son 3 madde ise "Anadili Bilgisi" olarak isimlendirilmiştir. Ölçeğin açıklanan yığılmalı varyans yüzdeleri sırasıyla; birinci faktör için 37,1; ikinci faktör için 42,3; üçüncü faktör için 47,1 ve dördüncü faktör için ise 52,7 olarak belirlenmiştir.Ölçeğin alt boyutları ve geneli için hesaplanan Cronbach Alfa değerlerine göre iç tutarlılık katsayılarının birinci faktör için 0,762 ; ikinci faktör için 0,705 ; üçüncü faktör için 0,699 ; dördüncü faktör için 0,657 ve ölçeğin tamamı için 0,728 olduğu görülmüştür. 


\section{Doğrulayıcı Faktör Analizine Yönelik Bulgular}

Doğrulayıcı faktör analizinde, yapının uygunluğu için model uygunluk ölçütlerinden RMSEA (Root Mean Square Error of Approximation) SRMR (Standardized Root Mean Square Residual), TLI (Tucker-Lewis index), CFI (Comparative Fit Index) ve Ki-kare değerleri dikkate alınmıştır. Literatürde TLI daha çok Benler-Bonnet Normlandırılmamış Uyum İndeksi (NNFI) olarak da bilinir. NNFI indeksi 0 ile 1 arasında değer alır. Yüksek (1'e yakın) NNFI değerleri daha iyi bir uyumu gösterir. Bu indeks de dikkat edilmesi gereken en önemli nokta normlandırılmadığ 1 için, değerler bazen 0-1 değer aralığı dışına çıkabilir. (Çerezci; 2010) Analiz sonuçlarına göre belirlenen dört faktörün 19 gözlenen değişkeni doğru bir şekilde yordayabildiğine dair bir eşitlik modeli kurulmuştur. Elde edilen sonuçlara göre modelin uygun olması durumunda 0,05 'in altında olması gereken RMSEA değerinin 0,052 ve SRMR değerinin, 0,053 olduğu belirlenmiştir. Ayrica NNFI değerinin 0,86 , CFI değerinin 0,89 olduğu ve Kikare (Chi-Square) test istatistiği sonucu da; $342.696 \mathrm{p}<0.05$ ile anlamlı çıkarak verilerin normal dağılım özelliğine sahip olduğunu göstermiştir (Kline, 2005; Çerezci, 2010; Aytaç ve Öngen,2012) Buradan hareketle uyum indeks değerlerine ait model uygunluğunun kabul edilebilir düzeyde ve modelin veri tarafından doğrulandığı görülmüştür. Modelin doğrulayıcı faktör analizi çözümlemesi Şekil 3'de verilmiştir; 
Şekil 3: Etkili Konuşma Özyeterlik Algı Ölçeğinin Doğrulayıcı Faktör Analizi Modeline ilişsin Standart Değer Diyagramı Yı̆̆ılma Grafiği

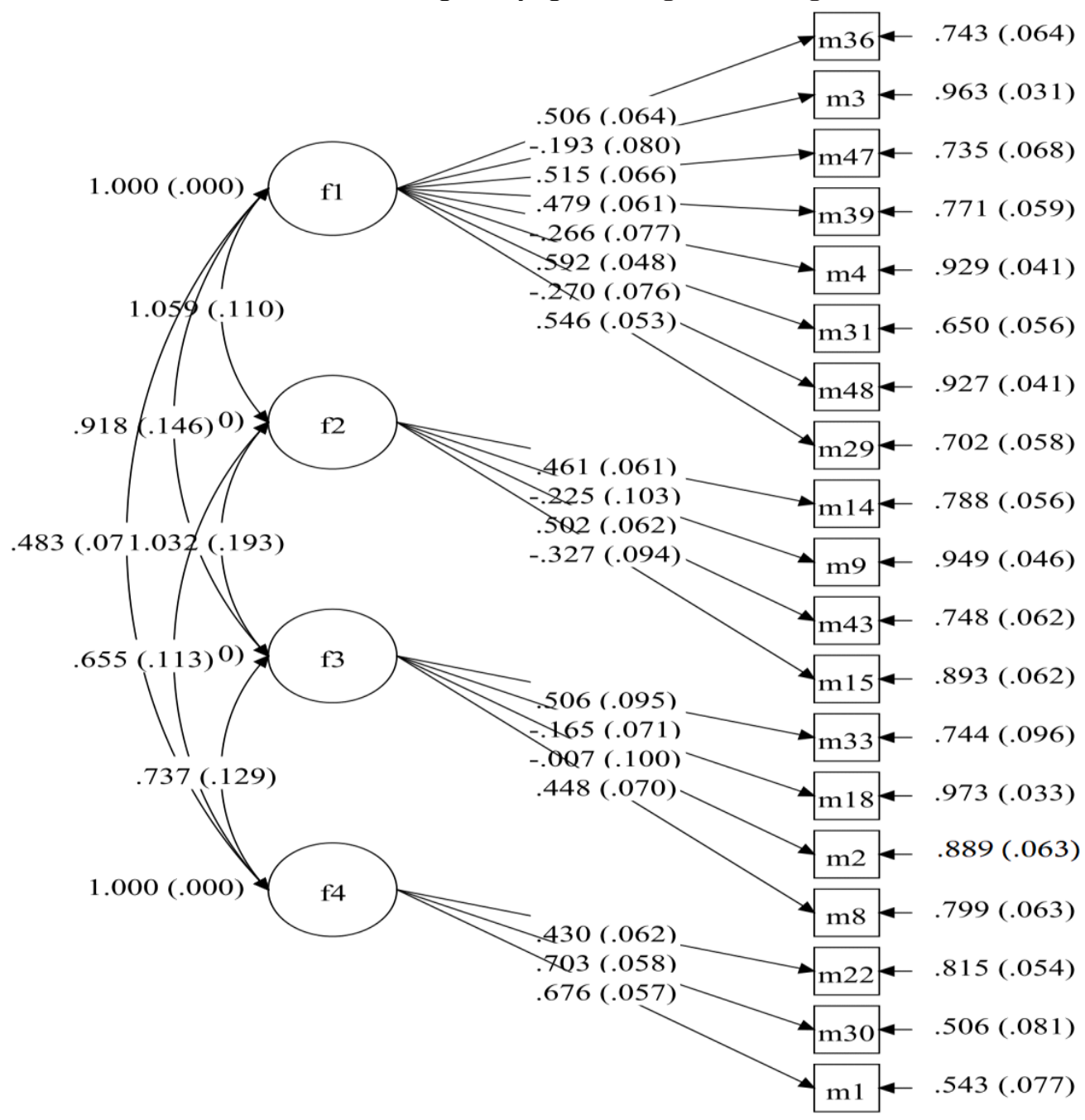

Chi-Square $=342.696, \mathrm{df}=109, \mathrm{P}$-value $=0.00000, \mathrm{RMSEA}=0,052$

\section{Ölçme Aracının İç Tutarlılık Güvenirliğine İlişskin Bulgular}

Ölçeğin güvenirlik çalışmaları iç tutarlılık katsayılarıyla incelenmiştir. Her bir madde için bağımsız gruplarda iki yönlü t-testi yapılmış ve madde analizi sonuçları Tablo 3'de verilmiştir. 
Tablo 3: Etkili Konuşma Özyeterlik Algı Ölçeğinin Seçilen Maddelerinin Ayırt Ediciliğine İlişkin t-Testi Analizi

\begin{tabular}{|c|c|c|c|c|c|c|c|}
\hline $\begin{array}{c}\text { Ölçek } \\
\text { Madde No }\end{array}$ & Grup & $\mathbf{N}$ & $\overline{\mathbf{X}}$ & Ss & sd & $\mathbf{t}$ & $\mathbf{p}$ \\
\hline \multirow[t]{2}{*}{1} & $\overline{\text { alt }}$ & 172 & 3,33 & .780 & 343 & $-28,127$ & $.0001 *$ \\
\hline & üst & 172 & 5,00 & .000 & 343 & $-28,046$ & $.0001 *$ \\
\hline \multirow[t]{2}{*}{2} & alt & 172 & 1,22 & ,412 & 343 & $-41,548$ & $.0001^{*}$ \\
\hline & üst & 172 & 3,90 &, 740 & 343 & $-41,611$ & $.0001 *$ \\
\hline \multirow[t]{2}{*}{3} & alt & 172 & 3,41 & ,770 & 343 & $-27,195$ & $.0001^{*}$ \\
\hline & üst & 172 & 5,00 &, 000 & 343 & $-27,116$ & $.0001 *$ \\
\hline \multirow[t]{2}{*}{4} & alt & 172 & 3,73 &, 641 & 343 & $-26-146$ & $.0001^{*}$ \\
\hline & üst & 172 & 5,00 & ,000 & 343 & $-26,070$ & $.0001 *$ \\
\hline \multirow[t]{2}{*}{5} & alt & 172 & 1,25 & ,434 & 343 & $-38,033$ & $.0001^{*}$ \\
\hline & üst & 172 & 3,88 & ,799 & 343 & $-38,093$ & $.0001 *$ \\
\hline \multirow[t]{2}{*}{6} & alt & 172 & 2,83 & 819 & 343 & $-34,911$ & $.0001^{*}$ \\
\hline & üst & 172 & 5,00 &, 000 & 343 & $-34,809$ & $.0001^{*}$ \\
\hline \multirow[t]{2}{*}{7} & alt & 172 & 2,58 & ,631 & 343 & $-50,562$ & $.0001^{*}$ \\
\hline & üst & 172 & 5,00 &, 000 & 343 & $-50,415$ & $.0001 *$ \\
\hline \multirow[t]{2}{*}{8} & alt & 172 & 1,00 & ,000 & 343 & $-44,114$ & $.0001 *$ \\
\hline & üst & 172 & 3,72 & ,809 & 343 & $-44,242$ & $.0001 *$ \\
\hline \multirow[t]{2}{*}{9} & alt & 172 & 2,69 & ,569 & 343 & $-53,382$ & $.0001^{*}$ \\
\hline & üst & 172 & 5,00 &, 000 & 343 & $-52,287$ & $.0001 *$ \\
\hline \multirow[t]{2}{*}{10} & alt & 172 & 1,00 & ,000 & 343 & $-45,642$ & $.0001^{*}$ \\
\hline & üst & 172 & 3,87 &, 825 & 343 & $-45,775$ & $.0001 *$ \\
\hline \multirow[t]{2}{*}{11} & alt & 172 & 2,49 & ,690 & 343 & $-47,876$ & $.0001 *$ \\
\hline & üst & 172 & 5,00 & ,000 & 343 & $-47,458$ & $.0001^{*}$ \\
\hline \multirow[t]{2}{*}{12} & alt & 172 & 1,51 &, 501 & 343 & $-56,687$ & $.0001^{*}$ \\
\hline & üst & 172 & 4,56 & ,498 & 343 & $-56,686$ & $.0001^{*}$ \\
\hline \multirow[t]{2}{*}{13} & alt & 172 & 1,81 &, 530 & 343 & $-53,332$ & $.0001 *$ \\
\hline & üst & 172 & 4,68 & ,467 & 343 & $-53,312$ & $.0001 *$ \\
\hline \multirow[t]{2}{*}{14} & alt & 172 & 1,00 & ,000 & 343 & $-57,872$ & $.0001^{*}$ \\
\hline & üst & 172 & 4,24 &, 731 & 343 & $-58,381$ & $.0001 *$ \\
\hline \multirow[t]{2}{*}{15} & alt & 172 & 2,22 &, 771 & 343 & $-42,882$ & $.0001^{*}$ \\
\hline & üst & 172 & 4,91 & ,291 & 343 & $-42,787$ & $.0001^{*}$ \\
\hline \multirow[t]{2}{*}{16} & alt & 172 & 2,33 & ,700 & 343 & $-50,259$ & $.0001^{*}$ \\
\hline & üst & 172 & 5,00 &, 000 & 343 & $-50,113$ & $.0001 *$ \\
\hline \multirow[t]{2}{*}{17} & alt & 172 & 1,12 &, 328 & 343 & $-74,945$ & $.0001^{*}$ \\
\hline & üst & 172 & 4,54 & ,500 & 343 & $-75,032$ & $.0001 *$ \\
\hline \multirow[t]{2}{*}{18} & alt & 172 & 2,28 &, 738 & 343 & $-48,415$ & $.0001^{*}$ \\
\hline & üst & 172 & 5,00 & ,000 & 343 & $-48,274$ & $.0001 *$ \\
\hline \multirow[t]{2}{*}{19} & alt & 172 & 1,35 & ,480 & 343 & $-68,653$ & $.0001 *$ \\
\hline & üst & 172 & 4,75 & ,437 & 343 & $-68,634$ & $.0001 *$ \\
\hline \multirow[t]{2}{*}{20} & alt & 172 & 1,59 & ,493 & 343 & $-61,202$ & $.0001^{*}$ \\
\hline & üst & 172 & 4,72 &, 452 & 343 & $-61,156$ & $.0001^{*}$ \\
\hline 21 & alt & 172 & 1,76 & ,666 & 343 & $-58,574$ & $.0001 *$ \\
\hline & üst & 172 & 4,93 & ,255 & 343 & $-58,447$ & $.0001 *$ \\
\hline 22 & alt & 172 & 1,27 & ,447 & 343 & $-34,487$ & $.0001^{*}$ \\
\hline & üst & 172 & 3,77 &, 838 & 343 & $-34,542$ & $.0001 *$ \\
\hline 23 & alt & 172 & 1,00 & ,000 & 343 & $-39,976$ & $.0001^{*}$ \\
\hline & üst & 172 & 3,66 &, 872 & 343 & $-40,093$ & $.0001 *$ \\
\hline 24 & alt & 172 & 1,53 & ,501 & 343 & $-91,195$ & $.0001 *$ \\
\hline & üst & 172 & 5,00 &, 000 & 343 & $-90,930$ & $.0001 *$ \\
\hline 25 & alt & 172 & 2,01 & ,769 & 343 & $-51,103$ & $.0001^{*}$ \\
\hline
\end{tabular}




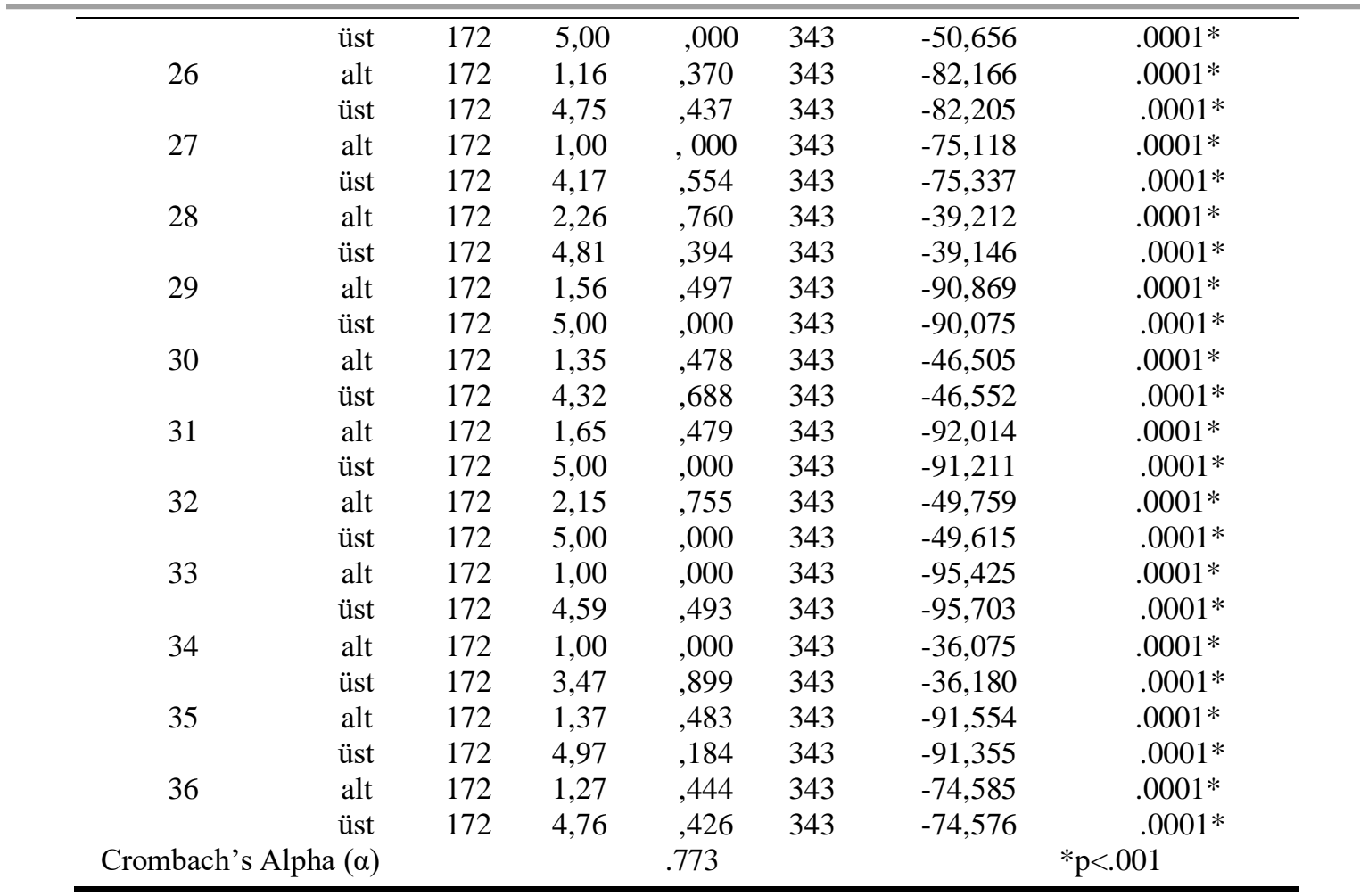

Tablo 3 incelendiğinde 36 maddelik deneme ölçme aracının Cronbach Alfa Katsayısı değeri $(\alpha=.773)$ ve t-testi sonuçlarına göre, ölçekte yer alan maddelerin tamamının anlamlı olduğu $(p<.000)$ ve bütün maddelerin etkili konuşma öz yeterlik algısını belirlemede ayırt edicilik özelliğine sahip olduğunu göstermektedir. Etkili konuşma öz yeterlik algı ölçeğine ilişkin elde edilen Cronbach Alfa Katsayısı değeri, ölçme aracının homojenliğinin bir göstergesi olarak kabul edilmekte olup, hesaplanan Cronbach Alfa Katsayısı 1'e yaklaştığı derecede ölçme aracının tek boyutlu bir yapıya sahip olduğu düşünülebilir. Öz damar (1999) 'a göre güvenirlik katsayısına ilişkin ölçüt değerleri aralığında0,61< $<<0,80$ olduğu zaman ölçek orta düzeyde güvenilirdir. Yukarıda verilen ölçüt değerlerine göre ölçeğin de kabul edilebilir düzeyde bir güvenirlik katsayısına sahip olduğu görülmüştür.

\section{Ölçüt Geçerliliğine Yönelik Bulgular}

Ölçeğin "ölçüt geçerliliğini” sınamak için, geliştirilen ölçek ile; Aydın (2013) tarafından geliştirilen "Öğretmen Adaylarının Konuşma Öz Yeterliklerine İlişkin Ölçek" uygulanmıştır. Bu ölçek ile üç farklı lisede öğrenim gören 10,11 ve 12. sinıflardaki toplam 90 öğrenciden veri toplanmış ve değerlendirilmiştir. Yapılan analiz neticesinde bu iki uygulamanın sonuçları arasında anlamlı bir ilişki tespit edilmiştir $(r=0,82 ; p<0,01)$. Ölçek dört boyutlu olup, iç-tutarlık katsayıları, ölçeğin bütünü için .95; "Konuşmayı Planlama" boyutu için .94, "Konuşma Süreci" boyutu .87, 3, "Dilsel Yapı" boyutu için 89 , 4ve "Dinleyici Faktörü" boyutu için ise .74 alfa katsayısına sahip olduğu görülmektedir. Bu ölçeğin faktör puanları arasındaki koreleayon değerleri aşağıda verilmiştir; 
Tablo 4: Ölçüt Geçerliğine İlişkin Kullanılan Ölçeğin Faktör Puanları Arasındaki Korelasyon Sonuçları

\begin{tabular}{llcccc}
\hline & $\begin{array}{c}\text { Madde } \\
\text { Sayıs1 }\end{array}$ & $\begin{array}{c}\text { Konuşmay1 } \\
\text { Planlama }\end{array}$ & $\begin{array}{c}\text { Konuşma } \\
\text { Süreci }\end{array}$ & $\begin{array}{c}\text { Dilsel } \\
\text { Yap1 }\end{array}$ & $\begin{array}{c}\text { Dinleyici } \\
\text { Faktörü }\end{array}$ \\
\hline Faktör 1 & 20 & - & $.63^{*}$ & $.70^{*}$ & $.47^{*}$ \\
Faktör 2 & 12 & $.63^{*}$ & - & $.63^{*}$ & $.48^{*}$ \\
Faktör 3 & 9 & $.70^{*}$ & $.63^{*}$ & - & $.45^{*}$ \\
Faktör 4 & 5 & $.47^{*}$ & $.48^{*}$ & $.45^{*}$ & - \\
\hline
\end{tabular}

$* \mathrm{p}<.001$

Tablo 4'e göre ölçüt geçerliğine ilişkin ölçeğin faktörleri arasında pozitif ve anlamlı ilişkilerin $(\mathrm{p}<.01)$ bulunduğu ve dört faktörden oluştuğu görülmektedir. Bu durum mevcut ölçeğin “ölçüt geçerliliğini”" sinamak için uygun olduğunu göstermektedir.

\section{Yansızlığa Yönelik Bulgular}

Geliştirilen ölçeğin uygulandığı alt gruplarda yansız ölçüm yapıp yapmadığını tespit etmek için alt grup olarak kabul edilebilecek gruplar araştırılmıştır. Cevaplayıcı alt gruplarının ırk ya da etnik köken, kültür, dil, cinsiyet, yaş, sosyoekonomik statü vb. göre sınıflamalara tabi tutulabileceği belirtilmektedir (AERA, APA, NCME, 1999; akt.. Özbay ve Uyar, 2009). Buradan hareketle cinsiyete, sınıf düzeyine ve yaşa bağlı grupların olası alt gruplar olduğu belirlenmiş ve analiz sonuçları Tablo 5'de verilmiştir.

Tablo 5: Etkili Konuşma Özyeterlik Alg1 Ölçeği’ninAlt Gruplarda Hesaplanan Güvenirlik Katsayıları

\begin{tabular}{lccccc}
\hline & Alt grup & Sesletim & Hazırlık & Beden Dili & Anadili Bilgisi \\
\hline \multirow{2}{*}{ Cinsiyet } & Erkek & 0,593 & 0,571 & 0,639 & 0,740 \\
& Kız & 0,713 & 0,607 & 0,699 & 0,715 \\
\multirow{3}{*}{ Sinıf Düzeyi } & 9 & 0,673 & 0,657 & 0,595 & 0,693 \\
& 10 & 0,623 & 0,610 & 0,773 & 0,776 \\
& 11 & 0,617 & 0,419 & 0,651 & 0,679 \\
Yaş & 12 & 0,784 & 0,607 & 0,760 & 0,837 \\
& 14 & 0,789 & 0,595 & 0,257 & 0,332 \\
& 15 & 0,601 & 0,650 & 0,667 & 0,732 \\
& 16 & 0,707 & 0,596 & 0,743 & 0,722 \\
& 17 & 0,582 & 0,509 & 0,661 & 0,734 \\
& 18 & 0,845 & 0,492 & 0,781 & 0,841 \\
\hline
\end{tabular}

Tablo 5'te de görüldüğü üzere ölçeğin "Hazırlık" boyutunun 11.sınıf öğrenciler için, "Beden dili" boyutunun 14 yaşındakiler için ve "Anadili bilgisi" boyutunun da 14 yaşındakiler için düşük bir güvenirlik katsayılarına sahip oldukları tespit edilmiştir. Ancak ölçeğin diğer boyutları ile ilgili güvenirlik katsayılarının gerekli asgari düzeyin üzerinde olduğu görülmüştür. Bu durumda ölçeğin diğer boyutlarından alınan puanlardan hareketle değerlendirme yapılması için bir engel bulunmamıştır.

\section{Tartışma ve Öneriler}

$\mathrm{Bu}$ araştırmada orta öğretim seviyesindeki öğrencilerin etkili konuşma yeterlik düzeylerini ölçebilmek açısından geçerli ve güvenilir bir "Etkili Konuşma Özyeterlik Algı Ölçeği”" geliştirmek amaçlanmıştır. Geliştirilen ölçek orta öğretim öğrencileri düzeyinde uygulanmıştır. Yapılan istatistik analizleri doğrultusunda "Etkili Konuşma Öz yeterlik Algı Ölçeği' nin açımlayıcı ve doğrulayıcı 
faktör analizi sonuçlarının kabul edilebilir düzeyde olduğu görülmüştür. Analiz sonuçlarından hareketle ölçeğin dört faktörlü bir yapıya sahip olduğu ve sunulan hali ile ölçeğin tek bir yapıyı (etkili konuşma eylemlerini) ölçtüğü söylenebilir. Ölçeğin iç tutarlılık katsayıs1, hem ölçeğin geneli için hem de alt faktörler için uygun düzeyde bulunmuştur. Bu değer aralıkları incelendiğinde ölçeğin yeterli güvenirliğe sahip olduğunu göstermektedir (Özbay ve Uyar, 2009) . Ayrıca ölçeğin uygulanacağı grubun alt gruplarında da güvenilir olması gerektiğinden buna yönelik kanıtlar da incelenmiştir. Elde edilen veriler ölçeğin "Hazırlık", "Beden dili" ve "Anadili bilgisi” boyutlarında alt grupta güvenilirlik düzeylerinin zayıf olmakla birlikte ölçeğin bütünü açısından ele alındığında güvenilirlik düzeyinin bu alt gruplar için de kabul edilebilir olduğu görülmüştür. Öğrencilerin etkili konuşma becerileri yanında, nefesi uygun ve düzenli kontrol etme, sesleri anadiline uygun şekilde telaffuz edebilme, uygun yerde durak, vurgu ve tonlama yapabilme, konuşma zamanının ve konuşma mekanını planlayabilme, beden dili gibi konular hakkındaki farkındalıklarının geliştirilebilmesi için ölçeğin faydalı olabileceği de düşünülmektedir.

Ülkemizde farklı eğitim öğretim kademelerinde genellikle öğrencilerin konuşma becerileri, yeterlikleri, tutumları ve bilişsel düzey farkındalıklarını tespit etmeyi amaçlayan araştırmalar yapılmış ve bu başlıklara ait ölçekler geliştirilerek kullanılmıştır. Ancak konuşma ölçeklerinin boyutlandırılması bakımından benzer isimlendirmelere yer verilmesine karşın bu araştırmada geliştirilen ölçeğin boyut isimlerinin farklı olması ve daha önceki çalışmalar da yer almaması önemli bulunmuştur. Örneğin; Demirel (1999) tarafindan geliştirilen Konuşma Ölçeği; telaffuz, tonlama, vurgulama, anlama, iletişim kelime ve dil bilgisi alt boyutlarından oluşmuştur. Çintaş ve Yavuz (2012) tarafından geliştirilen Etkili Konuşma Ölçeği ise sunum uslup ve ifade, konuşmaya odaklanma ve dinleyicileri dikkate alma gibi alt boyutları içermektedir. Kuzu ve Suna (2012) tarafından öğretmen adaylarına yönelik geliştirilen hazırlıklı konuşma ölçeği ise; cümlelerin kuruluşu, söz varlığı, jest, mimik ve beden dili kullanımı, bürün öğelerinin kullanımı boyutlarından oluşmaktadır. Kartallığglu (2015) tarafından geliştirilen Hazırlıklı Konuşmayı Değerlendirme Ölçeği ise; konuşma öncesi plan (dinleyici özellikleri, süre, görsel-işitsel araçlar, sorulara hazırlık, deneme, ek materyal), konuşma sırası (giriş, konuşma hızı, kitleye uygun dil, telaffuz, argo kullanımı, sözcük seçimi, ses tonu, beden dili, ara hitaplar, bağlaşıklık-tutarlılık, değer yargıları, kendinden emin olma, olumsuz davranışlardan kaçınma, el/kol hareketleri-içerik uyumu, göz teması, özetleme, bitiriş) ve konuşma sonrası (konuşmaya ilişkin öz-değerlendirme, soruları ve eleştirileri dinleme-yanıtlama) olmak üzere temelde üç boyutludur. Ünal ve Özer (2017) tarafından geliştirilen Ortaokul Öğrencileri İçin Konuşma Becerisi Tutum Ölçeği; konuşma becerisine yönelik ilgi ve sevgi ve konuşma becerisine karşı kaygı ve endişe olmak üzere iki boyutludur. Genel olarak araştırmacıların konuşma, etkili konuşma ve hazırlıklı konuşma gibi beceriler bakımından benzer alt boyutları kullandıkları söylenebilir. Ayrıca araştırmacıların ölçeklerinde yer alan alt boyutların birbirlerinden farklı olduğu görülmektedir.

Ancak araştırma kapsamında geliştirilen ölçek ile daha büyük örneklemler üzerinde çalışılarak daha genellenebilir veri toplanması beklenmektedir. Geliştirilen ve sunulan ölçek sayesinde elde edilecek farklı araştırma konularına ait verilerin çözümlenmesi sonunda alana katkı getirilebileceği düşünülmektedir. Farklı kademelerdeki öğrencilerin etkili konuşma becerilerinin geliştirilmesi için okullarda ve diğer eğitim kurumlarında farklı ders programlarının ve öğretim etkinliklerinin geliştirilmesine de katkı getirmesi beklenmektedir. Ölçek sayesinde elde edilecek verilerin sonuçlarına bağlı olarak, öğretim süreci boyunca yapılan etkinliklere rehberlik eden öğretmenleri de bu konuda bilinçlendirmek mümkün olabileceği gibi ana dili dersi öğretim programlarındaki konuşma kazanımlarının istenen hedeflere ulaşmasını kolaylaştırmayı da sağlayacaktır. Ayrıca ölçek boyutlarının bir kısmının yapılan benzer araştırmalarda yer almaması nedeniyle farklı düzeylerdeki öğrenciler üzerinde de kullanılabilmesi için gerekli geçerlik ve güvenirlik kanıtları toplanması gerektiği de söylenebilir. Böylece elde edilecek farklı sonuçların günümüzde orta öğretim ders programlarının güncellenmesine katkı getirmesi de beklenmektedir. 


\begin{tabular}{|c|c|c|c|c|c|c|}
\hline $\begin{array}{l}\text { Madde } \\
\text { No }\end{array}$ & 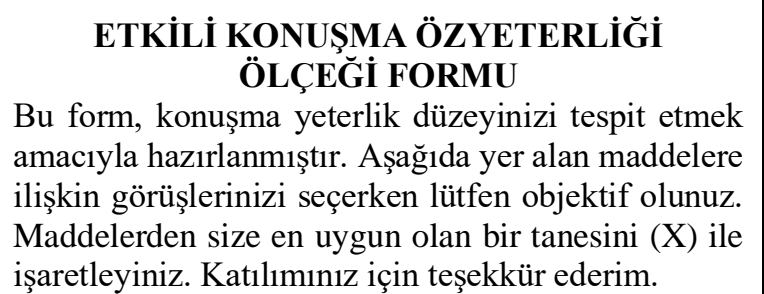 & $\begin{array}{c}\text { Her } \\
\text { zaman }\end{array}$ & Sıklıkla & Bazen & Nadiren & $\begin{array}{l}\text { Hiçbir } \\
\text { Zaman }\end{array}$ \\
\hline 1. & $\begin{array}{l}\text { Herhangi bir konuşmayı dinlerken ikna edici olup } \\
\text { olmadığına dikkat ederim }\end{array}$ & & & & & \\
\hline 2. & $\begin{array}{l}\text { Dinlediğim konuşmacının söyledikleriyle } \\
\text { hareketlerinin uyumuna önem vermem }\end{array}$ & & & & & \\
\hline 3. & $\begin{array}{l}\text { Bir ortamda bozuk ve çirkin konuşmanın kişiye } \\
\text { neler kaybettirebileceğinin farkına varabilirim }\end{array}$ & & & & & \\
\hline 4. & $\begin{array}{l}\text { Kendimi ifade ederken Türkçeyi doğru ve güzel } \\
\text { telaffuz edebilmenin avantajlarnın farkındayım }\end{array}$ & & & & & \\
\hline 5. & $\begin{array}{l}\text { Telaffuz sırasında kelimelerin doğru söyleniş } \\
\text { biçimlerini önemsemem }\end{array}$ & & & & & \\
\hline 6. & $\begin{array}{l}\text { Konuşma öncesinde duygu ve düşüncelerimi } \\
\text { dinleyici seviyesine göre daha iyi ifade edebileceğim } \\
\text { bir üslup seçebilirim }\end{array}$ & & & & & \\
\hline 7. & $\begin{array}{l}\text { Konuşma öncesinde sunuma uygun kiyafet } \\
\text { seçmeyi önemsemem }\end{array}$ & & & & & \\
\hline 8. & $\begin{array}{l}\text { Konuşma öncesinde prova almanın faydasına } \\
\text { inanırım. }\end{array}$ & & & & & \\
\hline 9. & $\begin{array}{l}\text { Konuşma yaparken dinleyicinin konu hakkında ana } \\
\text { fikre sahip olup olmadığını fark ederim }\end{array}$ & & & & & \\
\hline 10. & $\begin{array}{l}\text { Ben konusstuktan sonra arkadaşlarım genelde beni } \\
\text { yanlış anlarlar }\end{array}$ & & & & & \\
\hline 11. & $\begin{array}{l}\text { Ses sağlığımı korumak için uyulması gereken } \\
\text { hijyenik kuralların farkındayım }\end{array}$ & & & & & \\
\hline 12. & $\begin{array}{l}\text { Genellikle duygu ve düşüncelerimi anlatacak } \\
\text { kelimeleri bulamıorum }\end{array}$ & & & & & \\
\hline 13. & $\begin{array}{l}\text { Uygun beslenme ve ses sağlığı arasındaki ilişkinin } \\
\text { önemine inanırım }\end{array}$ & & & & & \\
\hline 14. &  & & & & & \\
\hline 15. & $\begin{array}{l}\text { Günlük yaşamda kullandığım bazı seslerin } \\
\text { karşıllı̆ının harf olarak alfabemizde yer almadığını } \\
\text { düşšnüyorum }\end{array}$ & & & & & \\
\hline 16. & $\begin{array}{l}\text { Konuşma sırasında önemli noktaların farklı ses tonu } \\
\text { ile vurgulanması gerektiğine inanırım }\end{array}$ & & & & & \\
\hline 17. & $\begin{array}{l}\text { Konuşmaya başlamadan önce konuşma } \\
\text { metninin dinleyici tarafindan incelenmesini } \\
\text { isterim }\end{array}$ & & & & & \\
\hline 18. & $\begin{array}{l}\text { Konuşmadaki peltekliği gidermek amacıyla } \\
\text { yapılması gereken egzersizlerin farkındayım }\end{array}$ & & & & & \\
\hline 19. & $\begin{array}{l}\text { Konuşma sırasındaki tutukluğu engellemek } \\
\text { amaçyla hangi tür metinlerin daha çok } \\
\text { okunması gerektiğinin farkındayım }\end{array}$ & & & & & \\
\hline
\end{tabular}




\section{Kaynakça}

ACTFL (2012). The ACTFL proficiencyguidelines: Speaking. Yonkers, NY: ACTFL.

Ahmet, A., Yılmaz, S., \&Demirbacak, H. Ş. (2017). Konuşmacıda kişisel güven ölçeği kısa türkçe formu nun geçerlik ve güvenirliği. Akademik Bakış Uluslararası Hakemli Sosyal Bilimler Dergisi, (59), 374-381.

Aydın, İ.S. (2013). Öğretmen adaylarının konuşma öz yeterliklerine ilişkin ölçek geliştirme çalışması. Akdeniz Eğitim Araştırmaları Dergisi, 14, 33-46.

Bozkurt, B, Ü. (2017). Türkçe anadili konuşucuları için konuşma becerisi değerlendirme çerçevesi önerisi. AnaDili Ĕgitimi Dergisi, 5(4), 924-947.

Council of Europe. (2001). CommonEuropeanframework of referenceforlanguages: Learning, teaching, assessment. Cambridge: CUP.

Çintaş-Yıldız, D. ve Yavuz, M. (2012). Etkili konuşma ölçeği: Bir ölçek geliştirme çalışması. TurkishStudies, 7 (2), 319-334.

Demirel, Ö. (1999). Öğretme sanatı. Ankara: Pegem Yayınları.

Douglas, D. (1994). QuantityandQuality in Speaking Test Performance. Language Testing, 23(4),479-486.

Ergenç, İ (1999). Dilbilimin Bakış Açısıyla Beyin, Popüler Bilim, Temmuz 1999, s.41-49.

Erdem, İ. (2013). Konuşma eğitimi esnasında karşılaşılan konuşma bozuklukları ve bunları düzeltme yollar1. Journal of SocialSciences/Sosyal Bilimler Dergisi, 6(11).

Erdem, A. ve Erdem, M. (2014). "Dinle İzle Anlat" dinleme ve konuşma yeterlikleri ölçeğinin geliştirilmesi. Ĕgitim ve Ögretim Araştırmaları Dergisi, 3(4), 418-432.

Kartallığlu, N. (2015). Bilişsel farkındalık stratejilerinin 7. sınıf öğrencilerinin konuşma becerilerini gelişstirmeye etkisi. Ankara: Gazi Üniversitesi, Yayımlanmamış Doktora Tezi.

Karadağ, M. (1997). Diksiyon bilgileri ve konuşma sanatı. BalıkesirAkademi Dergisi Yayınları.

Koç, Y ( 2012). Tiyatro ve Diksiyon Bilgisi, Literatürk Yayınları

Kuzu, T. ve Suna, H. E. (2012). Öğretmen adaylarına yönelik hazırlıklı konuşma ölçeği geliştirme çalışması. M. Aksan ve (Ed.) 5. Uluslararası Türkçenin Ĕgitimi-Öğretimi Kurultayı Bildiriler (ss.139-147). Mersin: Mersin Üniversitesi.

Layiç, Ş. (2007). Etkili iletişimin temeli: beden dili. Gelişim Yayınlanı, İstanbul.

MEB (2006). İlköğretim Türkçe dersi (6, 7, 8. sinıflar) öğretim programı. Ankara.

Meiron, B. E.,\&Schick, L. S. (2000, October). 12 Ratings, ratersand test performance: An exploratorystudy. In Fairnessandvalidation in languageassessment: Selectedpapersfromthe 19th Language TestingResearchColloquium, Orlando, Florida(Vol. 9, p. 153). Cambridge UniversityPress.

Özdem, Y., Alp, K., \& Başoğlu, C. (2003). Konuşma sanatı: diksiyon. Kariyer Yayıncılık.

Öztürk, S. Ç. (2002). Üniversite öğrencilerinin sözel anlatım becerileri”. Anadolu Üniversitesi Edebiyat Fakültesi Dergisi, 1(3), 231 - 250.

Öztahtalı, İ.İ. (2009). Uludağ Üniversitesi Fen Edebiyat Fakültesi (yayımlanmamış) Diksiyon Dersi notları, Bursa. 
Sallabaş, M. E. (2011). Aktif öğrenme yönteminin ilköğretim ikinci kademe öğrencilerinin konuşma becerilerine etkisi. Yayımlanmamış Doktora Tezi, Gazi Üniversitesi, Ankara.

Sallabaş, M. E. (2013). Türkçeyi yabancı dil olarak öğrenenler için konuşma öz yeterlik ölçeği: Geçerlilik ve güvenirlilik çalışması. Dumlupınar Üniversitesi Sosyal Bilimler Dergisi, 36, 261-270.

Sargın, M. (2006). İlköğretim öğrencilerinin konuşma becerilerinin değerlendirilmesi - Muğla ili örneğinde. Yayınlanmamış Yüksek Lisans Tezi, Muğla Üniversitesi, Muğla.

Sevim, O. (2012). Öğretmen adaylarına yönelik konuşma kaygısı ölçeğii: bir geçerlik ve güvenirlik çalışması. TurkishStudies, 7(2), 927-937.

Suroğlu Sofu, M. (2012). Öğretmen adaylarının konuşma kaygıları. Yayımlanmamış Yüksek Lisans Tezi). Sakarya Üniversitesi Eğitim Bilimleri Enstitüsü, Sakarya.

Taşer, S. (2000). Konuşma Eğitimi, İstanbul: Papirüs Yayınları.

Temizyürek F, Erdem İ, Temizkan M (2011). Konuşma eğitimi(2.Bask1). Ankara: Pegem A Yayınc1lk.

Ünal, F. T., Özer, F. Türkçe Öğretiminde Dinleme Becerisi İle İlgili Kaynakça Çalışması.

Ulum, H., Taşkaya S.M. (2017). Sınıf Öğretmenlerinin Öğrencilerin Konuşma Becerilerini Geliştirmek İçin Kullandıkları Etkinlikler. Çukurova Araştırmaları Dergisi, 3(2), 92-101.

Oğuzhan, K. (2013). Akıcı Konuşma Problemi Yaşayan İlköğretim 5. Sınıf Öğrencisinin Konuşma Becerisini Geliştirme. Uluslararası Türk Eğitim Bilimleri Dergisi,1, 88-105.

Yaman, E. (2007). Doğru Güzel ve Etkili Konuşma Sanatı. İstanbul: Savaş Yayınları.

Yı1maz, M. Y. (2006). Güzel ve Etkili Konuşmak İçin Diksiyon. İstanbul: Elit KültürYayınları.

Yörük, Y. (1998) İlköğretim Güzel Konuşma/Yazma,SerhatYayıncılık,İstanbul 